\title{
Implementation of the Non-Cash Food Aid Program in Social Protection in Gerih District and Geneng District, Ngawi District
}

\author{
Drs. Agus Wiyaka M.Si Dra. Endang Murti, M.Si \\ Faculty of Social and Political Sciences, Merdeka Madiun University
}

\begin{abstract}
Summary
In order to improve the effectiveness and accuracy of the target of channeling social assistance and to encourage financial inclusion, the President of the Republic of Indonesia provided direction so that social assistance and subsidies were distributed in non-cash, using the banking system. Non-Cash Food Aid (BPNT) is implemented to replace the rice assistance program for Prosperous Families (Rastra) which is realized in the form of non-cash and given to Beneficiary Families (KPM) which are provided monthly through an electronic account mechanism used to buy food at traders / e-warong that works with the bank. The specific objective was the Research on the Implementation Model of the Non-Cash Food Assistance Program (BPNT) in Social Protection in Gerih District and Geneng District, Ngawi District. expected to be an alternative poverty reduction method / strategy. The objectives in detail in this study are: 1) Describe the Implementation of the Non-Cash Food Assistance Program (BPNT) in Social Protection in Ngawi Regency, East Java.2) Knowing the Implementation of the Non-Cash Food Aid Program (BPNT) in Social Protection in Ngawi Regency, East Java . The study was conducted in 18 (eighteen) villages in the Ngawi Regency region using the Participatory Action Research (PAR) method, which is a study that actively involves all relevant parties and Beneficiary Families through in-depth interviews, sample selection is done through a multilevel random approach. In addition, it is evident that the social assistance provided by the government through Non-Cash Food Assistance in Ngawi District greatly provides new business opportunities for micro and medium entrepreneurs so as to encourage the growth of KUBE E-warong managed by recipients of Non-Cash Food Aid which ultimately increases independence disadvantaged people in the countryside Based on the findings of the researchers that the beneficiary communities in Ngawi Regency stated that the location of the e-warong was quite affordable with most of the recipient families of beneficiary families making it easier in the exchange of electronic coupons with food provided by the village e-shop. Most of the Beneficiary Families stated that the food in the form of rice and eggs received was of good quality and the supply was guaranteed according to a predetermined schedule. Because Non-Cash Food Assistance includes being successful in improving accuracy in terms of the amount and timing of aid distribution, reduction of queues, faster disbursement process, and significant reduction of technical problems faced in the field.
\end{abstract}

Keywords: Food, social protection, Poverty Reduction

DOI: 10.7176/PPAR/9-6-04

Publication date:June $30^{\text {th }} 2019$

\section{Background and Problems}

The government is currently taking effective steps so that the implementation of Non-Cash Food Units runs well. The way is by ensuring that KPM (Beneficiary Family) data is on target, ensuring E-Warong has been effective, and the need for socialization and education as a banking product literacy effort to KPM, the Food Social Assistance program is a government effort to support the quality of life of people who unable. Overall, food social assistance will be provided to around 15.5 million Beneficiary Families (KPM) and given in the form of Non-Cash Food Aid (BPNT) to 1.2 million KPM and Rice Bansos for Prosperous People (Rastra) to 14.3 million KPM. The expansion of the distribution of BPNT in 2018 will be carried out in 4 stages; namely stage I in February, stage II in March, stage III in July, and stage IV in August so that the total KPM of the Food Social Security program is 15,498,936 KPM spread in 514 Regencies / Cities. But because President Jokowi requested the implementation of BPNT to be evaluated first, then in 2018 the implementation was postponed. But there are some things that we should pay more attention to than the recipient's data problem. Non-Cash Food Aid (BPNT) or the initial term food voucher is very thick with a "free market" nuance popularly known as "market mechanism". Two points that we should take into account are volatile prices and freedom of choice of rice. The price of equilibrium or the price of commodity reductions by beneficiary communities is largely determined by the strength of the seller and the buyer so that it cannot be controlled. In addition, the poor / vulnerable people who have received raskin for decades have suddenly chosen their own types of rice according to their taste. These two points are what the government has always proud of as the superiority of BPNT compared to literature. In economic activity, demand and supply are reflections of activity in the market, between prospective buyers and sellers. So that the meeting will form a price balance due to polarization caused by the market mechanism. In other words, the equilibrium price is formed by the activity of demand and supply. In the context above, when Rastra shifts to BPNT, there will be a new demand for around 17.8 million Target Households (RTS) that will enter the market. Whereas the quantity of rice that will be requested is 2.78 million tons. Here it means, if we allocate Rp. 110 thousand / month, we multiply 12 
(one year) to get Rp. 1,320,000 / RTS. However, if we multiply it by 17.8 million RTS, the figure will be very phenomenal at IDR 3.7 Trillion. When compared to the condition of the previous year, as of March 2017 to March 2018 , the poverty rate in Indonesia has fallen by approximately 1.8 million people, considering that the poverty rate in March 2017 was still at 27.77 million people (10.64 percent). The percentage of poverty rate of 9.82 percent as of March 2018 is the lowest number in the history of the Republic of Indonesia. This achievement, according to BPS, was caused by, among others, social assistance increased by 87.6 percent. For the Ministry of Social Affairs itself, there are non-cash assistance programs the Hope Family Program (PKH), Non-Cash Food Aid (BPNT), and Prosperous Rice (Rastra).

\section{Research methods}

Achievements and Stages of Research: This study uses the Participatory Action Research (PAR) method, according to Agus Afandi (2014) research that actively involves all relevant parties (stakeholders) in reviewing ongoing actions (where their own experience as a problem) in order to make changes and improvements in a better direction while the activities carried out in the achievements and stages of research include:

1. Identifying problems / Finding problems: This stage, researchers must first look for what problems they want to examine.

2. Formulate a problem: Where at this stage is a continuation of the discovery of the problem, the researcher then formulates the problem based on the problems to be studied. Make it operational and make the boundaries of the problem especially in determining the scope of the problem under study.

3. Hold a preliminary study: This is done in order to gather information relating to the problem to be studied. So that it can be known the situation or position of the problem both theoretically and practically. Knowledge obtained from preliminary studies is very useful for compiling theoretical frameworks about problem solving in the form of hypotheses that will be verified through the implementation of field research. Preliminary studies can be done with documentary studies, literature and field studies.

4. Determine the study sample: At this stage, the object to be studied is determined. The entire object to be examined is called the research population. If the study only uses a portion of the population, then in this case simply use a sample.

5. Develop a research plan: This stage is a guideline during conducting research. As a pattern of planning must be able to reveal things related to the implementation of research activities.

Location and Object of Research: The understanding of the object of research according to Sugiyono (2012: 13), "The object of research is the scientific goal to obtain data with specific objectives and uses about something objective, valid, and reliable about a thing (certain variables)". The location and object of research in the area of Ngawi Regency as an area that represents / reflects the western part of East Java community in terms of aspects of society with traditional culture and industry, agriculture and plantations.

Research Samples and Respondents: Gay Opinion and Diehl (1992) assume that the more samples taken, the more representative and the results can be digitized. But the size of the sample received will depend on the type of research. Sampling uses a multi stage sampling technique, and the research subjects are Government and society in Ngawi Regency, East Java, which is represented by government officials and the community in the Geneng District and Gerih District, Ngawi District. Next part is taken to be made sample / respondent of the study by "Purposive Sampling". The definition of purposive sampling technique according to Arikunto is a technique of taking samples not based on random, regional or strata, but based on the existence of considerations that focus on specific goals. (Arikunto: 2006).

Data Collection Techniques: Data collection techniques are a way of collecting data needed to answer the research problem formulation. Juliansyah Noor (2011: 138). Data collection techniques used in this study are interviews (interviews), observations (observations), and documents (documentation). While to test the validity of the data is to use Triangulation of data sources.

Research Analysis Methods: Methods of data analysis using interactive models. According to Matthew B. Miles and Michael Huberman in Moleong (2000), explained that in carrying out the analysis process the main components that need to be considered after data collection are:

1. Data reduction, namely the process of selecting, simplifying, abstracting and transforming rough data from written records in the field until the final complete report is arranged.

2. Presentation of data, namely a set of information arranged in order to give the possibility of drawing conclusions. In presenting this data, it is done after reducing the data to be used as report material.

3. Draw conclusions or verification, namely in the form of essence of the presentation of data which is the result of the analysis carried out in the study.

\section{Results and Discussion}

The program established by the Government to reduce the burden on the community in fulfilling basic needs is the Non-Cash Food Aid Program (BPNT). The BPNT program is food aid that is distributed in non-cash from the 
government to Beneficiary Families (KPM) every month, through an electronic account mechanism that is used only to buy food in a place that has collaborated with Bank Himbara. The BPNT program is organized by the government, in order to increase effectiveness and efficiency, the accuracy of the target of distributing social assistance and encourage financial inclusion, and to reduce the burden of expenditure and provide more balanced nutrition to the Beneficiary Families (KPM) on target and on time to support the implementation of the BPNT program. The BPNT program is able to reduce the burden of expenditure through fulfilling some food needs, providing balanced nutrition to KPM participants, increasing the accuracy of the target and timing of receipt of food aid and encouraging sustainable development. Scheme of Non-Cash Food Aid Program (BPNT). Each Beneficiary Family (KPM) receives social assistance of Rp 110,000 thousand, which is transferred every month through electronic Family Welfare Cards (KKS). With the existence of KKS, KPM participants can buy food needs in the form of rice and eggs through agents available in certain locations. The BPNT program is a government effort to help reduce the expenditure burden on the poor. This program is assumed to be able to influence KPM household expenditure patterns. From the example above, of course the Non-Cash Food Aid carried out in Ngawi Regency is inseparable from the Beneficiary Families in accordance with the integrated database at the Ngawi District Social Service office. The problem that arises is whether Poverty in Ngawi Regency has been grouped into four groups namely Absolute Poverty, Relative Poverty, Structural Poverty, Cultural Poverty. The four certifications will be elaborated by researchers so that various parties, especially those who handle Non-Cash Food Aid, can be identified

1. Absolute poverty is poverty caused by large incomes that are unable to meet their daily needs. This is also seen from the comparison of the poverty line (provety line).

2. Relative poverty is poverty that is determined by its environmental conditions as a result of inequality in income distribution which causes inefficient allocation of resources. This imbalance is obtained from the gini ratio.

3. Structural poverty is poverty caused by imbalances in the economic structure of a country.

4. Cultural poverty is poverty associated with socio-cultural values of society, or socio-cultural conditions that make people in the area forced to become poor.

Of the four poverty groups above, of course, good data officers from the Ngawi Regency Statistical Office and Village Devices in the Ngawi Regency area must be observant in entering the data of the poor into integrated database as a guideline in the provision of Non-Cash Food Aid. Living in poverty does not only mean living in a condition of lack of food, clothing and shelter. But poverty also means low access to resources and productive assets to obtain living needs. The Non-Cash Food Rock Policy is one of the government's efforts in tackling social poverty through rescue and social protection programs. Food is one of the strategic commodities for the community, therefore the government has an interest in maintaining price stability so as not to cause social turmoil. The role of food commodities on the poverty line is very large compared to other commodities. Rice is one of the food commodities that affects the poverty line. Given the important aspects of the success of the Non-Cash Food Stone program for efforts to maintain food security, it is necessary to support all parties (stakeholders) so that the implementation can run in accordance with the objectives of the policy. However, from various strategic aspects in the stages of the implementation of Non-Cash Food Rock Distribution, it always contains resistance factors in the occurrence of errors and even irregularities in the distribution of Non-Cash Food Rocks.

\section{Conclusion}

From the research findings, the Implementation Model of the Non-Cash Food Assistance Program (BPNT) in Social Protection in Gerih District and Geneng Sub-District, Ngawi Regency can be assessed for the implementation of the Non-Cash Food Assistance Program (BPNT) throughout 2018 most of the Beneficiary Families (KPM) expressed satisfaction at the implementation process while the E-warong manager also expressed satisfaction with the implementation of the program. From the research indicators show that Beneficiary Families and E-warong both feel that the activities of the 2018 Non-Cash Food Assistance Program implemented in Ngawi Regency are very easy to understand and comfortable, so that both Beneficiary Families and E-warong experience the benefits positively from the implementation of the Non-Cash Food Aid, which was the first to be carried out as a substitute for the Prosperous Rice Family program. The study was conducted in 18 (eighteen) villages in the Ngawi Regency region using the Participatory Action Research (PAR) method, which was a study actively involve all relevant parties and Beneficiary Families through in-depth interviews and sample selection through a multilevel random approach. It turned out and proved that the social assistance provided by the government through NonCash Food Assistance in Ngawi District greatly provided new business opportunities for micro and medium entrepreneurs so as to encourage the growth of KUBE E-warong managed by recipients of Non-Cash Food Aid which eventually increased independence of the rural poor. Based on the findings of the researchers that the beneficiary communities in Ngawi District stated that the location of the e-warong was quite affordable with most of the recipient families of beneficiary families making it easier in the electronic card exchange transaction with food provided by the village e-shop. Most of the Beneficiary Families stated that the food in the form of rice and eggs received was of good quality and the supply was guaranteed according to a predetermined schedule. Because 
Non-Cash Food Assistance includes being successful in improving accuracy in terms of the amount and timing of aid distribution, reduction of queues, faster disbursement process, and significant reduction of technical problems faced in the field. Viewed from the E-warong side as a channeling agent, the government is given the freedom to choose suppliers of food in this case rice and eggs with large traders or direct producers, in this case farmers or rice milling companies in the Ngawi Regency region in BPNT program cooperation, this can increase income, especially farmers and milling companies in Ngawi Regency. In the study, it was also on the surface of most Beneficiary Families including those who had their first bank account through the Prosperous Family Card, this shows the fact that Non-Cash Food Assistance in Ngawi District is very helpful for micro businesses to be accustomed to digital payments, so that expected to accelerate and encourage efforts from the government with the banking sector with the National Non-Cash Movement. It is expected that the results of this study can support government programs and all stakeholders to take steps or policies needed in an effort to improve the distribution of Non-Cash Food Aid, especially in rural areas, especially related to program socialization, disbursement mechanisms and distribution of social assistance.

\section{REFERENCES}

Afandi, Agus. 2014. Modul Participatory Action Research (PAR), Untuk Pengorganisasian Masyarakat (Community Organizing. Surabaya :Lembaga Penelitian dan Pengabdian Kepada Masyarakat (LPPM) UIN Sunan Ampel

AgusWiyaka, EndangMurti, Journal International Developing Country Studies www.iiste.org ISSN 2224-607X (Paper) ISSN 2225-0565 (Online) Vol.7, No.9, 2017 Model of Rastra Program in the Framework of Social Protection of Pre-Prosperous Society in Kendal District, Gerih and Kwadungan of Ngawi Regency

Arikunto, S. 2006. Prosedur Penelitian Suatu Pendekatan Praktik, Jakarta : Rineka Cipta.

Gay, L.R. dan Diehl, P.L. (1992), Research Methods for Business and. Management, MacMillan Publishing Company, New York

Noor, Juliansyah, Metodologi Penelitian : Skripsi, Tesis, Disertasi, \& Karya Ilmiah, Jakarta: Kencana Prenada Media Group, 2011.

J. Moleong, Lexy. 2000. Metode Penelitian Kualitatif. Remaja Rosdakarya; Bandung.

Sugiyono. 2012. Memahami Penelitian Kualitatif'. Bandung : Alfabeta.

Materi Sosialisasi Bantuan Pangan Non Tunai (BPNT), Maret 2018, Jakarta 